\begin{tabular}{|c|c|c|}
\hline NA & $\begin{array}{c}\text { Науковий вісник НЛТУ України } \\
\text { Scientific Bulletin of UNFU } \\
\text { http://nv.nltu.edu.ua }\end{array}$ & $\begin{array}{l}\text { (c) I ISSN 1994-7836 (print) } \\
\text { BY ISSN 2519-2477 (online) }\end{array}$ \\
\hline HヘT늘 & https://doi.org/10.15421/40290305 & \multirow{3}{*}{$\begin{array}{r}@ \varangle \text { Correspondence author } \\
\text { N. M. Turovtseva } \\
\text { natali.turovceva@ukr.net }\end{array}$} \\
\hline & $\begin{array}{l}\text { Article received 05.04.2019 p. } \\
\text { Article accepted 25.04.2019p. }\end{array}$ & \\
\hline & УДК [635.012:745.9]:378.4(477.64-21) & \\
\hline
\end{tabular}

Ю. Л. Бредіхіна', Н. М. Туровцева², О. Є. Пюрко2, Л. Г. Вельчева ${ }^{2}$

${ }^{1}$ Хортицька національна навчально-реабілітаційна академія, м. Запоріжжя, Украӥна

${ }^{2}$ Мелітопольський державний педагогічний університет ім. Богдана Хмельницького, м. Мелітополь, Украӥна

\title{
ДОСВІД ВИРОЩУВАННЯ, ЗАГОТІВЛІ ТА ВИКОРИСТАННЯ РОСЛИННОГО МАТЕРІАЛУ МАЛОПОШИРЕНИХ СІЛЬСЬКОГОСПОДАРСЬКИХ КУЛЬТУР В АРАНЖУВАННІ
}

Встановлено, що малопоширені сільськогосподарські культури можна використовувати як сухий (консервований) рослинний матеріал в об'ємному та напівоб'ємному різновидах композицій. Це такі рослини, як: бавовник звичайний, бамія, кенаф, канатник, сафлор красильний та розторопша плямиста. Результати візуальних багаторічних спостережень показали високу посухостійкість цих рослин в умовах Агробіологічного комплексу МДПУ ім. Б. Хмельницького. Досліджувані рослини без помітних пошкоджень витримують затяжні періоди посухи, які характерні для Південного Степу та не потребують особливих умов вирощування. Окремо для кожної культури визначено особливості заготівлі аранжувального матеріалу - термін збирання, консервування та умови зберігання. З'ясовано, що плоди або суцвіття цих рослин мають декоративні властивості, їх можна використовувати в композиціях як формоутворювальний основний рослинний матеріал та як матеріал-наповнювач. Для них доцільно використовувати природний спосіб об'ємного консервування - сушіння в польових умовах на колекційній ділянці. Окрім цього, перевагами цього рослинного матеріалу є його оригінальність, доступність, простота вирощування та тривалість зберігання. Оскільки ці рослини можна вважати перспективними для декоративної флористики, їх доцільно не тільки впроваджувати в навчальний процес під час вивчення дисциплін "Основи аранжування" та "Фітодизайн", але й включати в перелік рекомендованих рослин для аранжування у професійній літературі.

Ключові слова: колекційна ділянка; однорічні рослини; консервований рослинний матеріал; композиція; навчальний процес; декоративна флористика.

Вступ. У сучасному світі, коли людина дедалі більше залежить від техніки і технологій, що особливо стосується міських жителів, дуже важливо не втратити зв'язок із природою (Puzyrenko, 2013). Художні композиції із консервованих рослин не потребують особливого догляду і завдяки новим прийомам висушування в поєднанні з цікавими матеріалами виглядають яскраво та ефектно і зберігають природну красу рослин протягом тривалого часу. Природний матеріал, зокрема сухий рослинний, надає особливої елегантності також композиціям із живих квітів.

Мистецтво використання сухого рослинного матеріалу має багатовікову історію. Про це свідчать численні археологічні знахідки, зразки образотворчого мистецтва та поезії. Перші композиції із сухих рослин з'явилися в Сгипті у вигляді складних гірлянд із різноманітних трав, якими прикрашали палаци та гробниці фараонів (Diachuk, Perfilieva \& Perfilieva, 2013). Сухі рослини здавна використовували в традиційному японському

мистецтві складання композицій - ікебані. У другій половині XIX ст. входять в моду букети із засушених квітів, які запропонував австрійський художник Ганс Макарт. Вони складалися із сухих пофарбованих і натуральних трав, великого пальмового листя, сухих плодів, павиного та страусиного пір'я, шовкових та штучних виробів (Tabunshhikov, 2006; Rozemi, 1997). На початку $\mathrm{XX} \mathrm{ст.} \mathrm{інтерес} \mathrm{до} \mathrm{композицій} \mathrm{із} \mathrm{сухого} \mathrm{рослинного} \mathrm{ма-}$ теріалу помітно припиняється, тому що жорсткі та часто запилені букети почали сприймати як символ моди вікторіанської епохи (Khessaion, 2004). Можливо, це пов'язано також $з$ низькою якістю консервованих рослин: тьмяні барви, крихкість та відсутність природної форми. I тільки нещодавно було розроблено сучасні технології консервування оранжувального матеріалу, які дають змогу забезпечити його високу якість, завдяки чому він не поступається за красою та оригінальністю перед живими квітами. Останнім часом дедалі більше набуває популярності виготовлення авторських ро-

Інформація про авторів:

Бредіхіна Юлія Леонідівна, канд. с.-г. наук, доцент, кафедра садово-паркового господарства. Email: сvetochek_jul@ukr.net; https://orcid.org/0000-0001-9284-1082

Туровцева Наталія Миколаївна, канд. с.-г. наук, доцент, кафедра ботаніки і садово-паркового господарства. Email: natali.turovceva@ukr.net; https://orcid.org/0000-0001-6853-6328

Пюрко Ольга Євгенівна, канд. біол. наук, доцент, кафедра ботаніки і садово-паркового господарства. Email: diser0303@gmail.com

Вельчева Людмила Григорівна, канд. біол. наук, доцент, кафедра ботаніки і садово-паркового господарства. Email: velchevaug@ukr.net; https://orcid.org/0000-0001-9541-1061

Цитування за ДСту: Бредіхіна Ю. Л., Туровцева Н. М., Пюрко О. Є., Вельчева Л. Г. Досвід вирощування, заготівлі та використання рослинного матеріалу малопоширених сільськогосподарських культур в аранжуванні. Науковий вісник Нлту України. 2019, т. 29, № 3. C. 27-31.

Citation APA: Bredykhina, Yu. L., Turovtseva, N. M., Pyurko, O. E., \& Velcheva, L. G. (2019). Experience of cultivation, harvesting and use of plant material of rare agricultural crops in arranging. Scientific Bulletin of UNFU, 29(3), 27-31. https://doi.org/10.15421/40290305

Науковий вісник НЛтУ України, 2019, т. 29, № 3

Scientific Bulletin of UNFU, 2019, vol. 29, no 3 
біт, зокрема із сухого рослинного матеріалу, таких як: флористичний колаж, панно, букети у вазі тощо.

Мета роботи - розширити асортимент рослинного матеріалу для аранжування за рахунок малопоширених сільськогосподарських культур. Описати особливості їх вирощування та заготівлі (збір, консервування та зберігання) для аранжування.

Методи і методики дослідження. Для отримання об'єктивної і всебічної оцінки щодо вирощування культур використано спеціальні та загальні методи досліджень. Із загальних методів - комплексний підхід до з'ясування особливостей використання цих рослин в об'ємних композиціях, а із спеціальних - спостереження у польових умовах (визначення особливостей вирощування та термінів збирання), лабораторні методи (визначення методів консервування та умов зберігання) та фітодизайнологічні.

Об'єктом дослідження є декоративні властивості малопоширених сільськогосподарських культур, що зростають на колекційній ділянці агробіологічного комплексу МДПУ ім. Б. Хмельницького.

Результати дослідження та їх обговорення. Агробіологічний комплекс МДПУ ім. Б. Хмельницького розташовано на ділянці площею 4,5 га у західній частині м. Мелітополь Запорізької обл. Клімат міста характеризується невеликою кількістю опадів, сухістю повітря та інтенсивним випаровуванням вологи в літній період. Грунт на території комплексу - супіщаний чорнозем.

Колекційна ділянка польових та овочевих культур має загальну площу $800 \mathrm{~m}^{2} \mathrm{i} \epsilon$ базою для проведення навчальної практики 3 дисципліни "Основи сільського господарства" для студентів спеціальності "Біологія". На ділянці вирощують понад 60 видів польових, овочевих та лікарських рослин, серед яких є досить рідкісні культури для України, такі як: бавовник звичайний, бамія, кенаф, канатник, сафлор красильний та розторопша плямиста. Це однорічні рослини, яких немає в переліку рекомендованих рослин для аранжування у професійній літературі (Diachuk, Perfilieva \& Perfilieva, 2013; Puzyrenko, 2013).

Художнє конструювання з об'ємно висушених рослин - це складна творча робота, що потребує певних знань та навичок щодо заготівлі рослинного матеріалу та принципів композиційного дизайну. Заготівля рослинного матеріалу для композиції починається з добору асортименту рослин, потребує дотримання оптимальних термінів збирання, ретельного вибору способів консервування рослин та умов їх зберігання.

Консервацією називають усі способи оброблення рослинного матеріалу, які спрямовані на максимальне збереження найбільш привабливих частин та природних властивостей рослин, таких як: кольорова гама, форма і фактура. Існує декілька способів об'ємної консервації рослин: сушіння на повітрі, сушіння за допомогою речовин, що поглинають воду, консервація за допомогою гліцерину, сушіння у мікрохвильовій печі, сушіння у духовці [9].

Для більшості видів, які використовують для консервації, характерні невибагливість до умов вирощування і стійкість проти несприятливих чинників погоди. Вони характеризуються як посухостійкі та світлолюбні рослини. Під час досліджень виявили, що малопоширені сільськогосподарські культури можуть бути викорис- тані в об'ємній та напівоб'ємній флористиці. Нижче наводимо опис цих рослин.

Бавовник звичайний (Gossypium hirsutum L.), родина Мальвові (Malvaceae). Бавовник - важлива технічна культура світового рослинництва. Декілька тисяч років тому в Азії, Америці та Африці було окультурено різні види бавовнику. Сьогодні вирощують два види: бавовник звичайний (батьківщина Мексика) і бавовник тонковолокнистий (батьківщина Перу) (Lebedeva, 1985).

В Україні бавовник почали вирощувати в 1929 р. Південні області нашої країни стали північною базою бавовництва у світі. Проте в 1954 р. сіяти бавовник в Україні припинили через його високу вартість, низьку врожайність та якість волокна. Зараз пробують повернутися до вирощування бавовнику, що зумовлене тим, що найбільший в Свропі Херсонський бавовняний комбінат після розпаду Радянського Союзу залишився без сировини. Проте перспектива українського бавовництва залишається поки що проблематичною через відсутність обгрунтованої державної програми його розвитку. Але сьогодні ні в кого не виникає сумніву стосовно можливості культивування бавовнику в умовах півдня України. Якщо для всіх сільськогосподарських культур, які вирощують у Південному регіоні, лімітуючим чинником є вода, то для бавовнику цієї проблеми не існує (Zhatov et al., 2013).

На колекційній ділянці впродовж 10 років культивуємо скоростиглий сорт "Дніпровський 5" селекції Інституту зрошуваного землеробства НААН (м. Херсон). Його рекомендовано для вирощування в умовах Степової зони України (Reiestr, 2019). Протягом усього періоду вирощування його біометричні показники повністю відповідали заявленим для цього сорту. Тільки в один рік коробочка не розкрилася через різке зниження температури на початку жовтня.

У сівозміні бавовник розміщуємо після кукурудзи або зернобобових. Передпосівну підготовку проводимо способом замочування у воді впродовж однієї доби. Термін сівби пізній і припадає на першу - другу декаду травня. У цей час температура грунту на глибині $10 \mathrm{~cm}$ не нижча $12-15^{\circ} \mathrm{C}$. Спосіб сівби широкорядний 3 відстанню між рядами 70 см. Насіння загортаємо на глибину 4-5 см. Полив за мірою необхідності.

Для створення композицій використовуємо плоди. Плід бавовнику - це 3-5-гніздова коробочка, яка в сухому стані має розмір 4-5 см. Спосіб консервування повітряне сушіння на рослині. Термін збирання для аранжування - після розтріскування коробочки, в II-III декаді жовтня. У композиціях бавовник можна використовувати як основний матеріал або наповнювач.

Бамія (гібіск їстівний, окра) (Abelmoschus esculentus (L.) Moench., Hibiscus esculentus L., Okra) - однорічна рослина родини Мальвових (Malvaceae), плоди якої (недозрілі 3-6-денної зав'язі) є цінним дієтичним продуктом, багатим на білкові речовини, аскорбінову кислоту, містять каротин і вітаміни групи В (Khaleba \& Unuchko, 2013). Раніше поширеною назвою була "бамія", але останнім часом їі частіше називають "гібіск їстівний". Також у літературних джерелах трапляються назви "абельмосхус", "гомбо", "окра", "дамські пальчики". Вона дуже поширена у світі (країни Свропи, Азії, Африки у Америки). Нині в Україні ця рослина досить по- 
пулярна серед городників i дачників (Pozniak, Kharytskyi \& Malenko, 2007).

Упродовж останніх 5 років вирощуємо середньостиглий, низькорослий сорт "Діброва" селекції Інституту овочівництва і баштанництва НААН (м. Харків) (Reiestr, 2019). Висівання здійснюємо наприкінці квітня - на початку травня. Спосіб сівби гніздовий, глибина загортання насіння - 2-3 см. Перед висіванням насіння замочуємо в теплій воді $\left(45^{\circ} \mathrm{C}\right)$ впродовж 1,5 год. До попередників бамія невимоглива. Полив у разі необхідності.

Для створення композицій використовуємо плоди. Плід бамії - подовжена п'ятигранна багатонасінна коробочка пірамідальної форми, яка у сухому стані має довжину 6-8 см. Спосіб консервування - повітряне сушіння на рослині. Час збирання для аранжування - III декада липня - IV декада вересня. Для використання у композиціях бамія може бути формоутворювальним або основним матеріалом.

Канатник (Abutilon theophrasti Medik.) - однорічна рослина 3 родини Мальвових (Malvaceae). У дикому стані канатник поширений на Кавказі, в Казахстані, в країнах Середньої і Південної Свропи та Азії; росте також в Австралії, Америці, Африці. Центр походження культури канатника - Північний Китай. Рослина культивується в Кореї та Японії.

Виділяють 2 форми канатника: культурну та дикорослу. У культурного канатника стебло пряме, не розгалужене, зелене або фіолетове 3 коротким густим опушенням заввишки до 2,5-3 м і вище. Плід - складна листянка, що складається з 11-30 плодолистиків і містить 35-45 насінин. За даними С. В. Міщенко, висота у культурних форм може сягати 4,5 м (Mishchenko, 2012). В умовах колекційної ділянки висота рослин становила $2,0-2,5 \mathrm{M}$.

Канатник вирощують для отримання волокна з лубу стебла. Волокно використовують (часто в суміші з волокном інших рослин) для виготовлення мішковини, мотузок, канатів, шпагату, щіток та інших виробів, частково замінюючи волокно джуту. Вирощуємо канатник на колекційній ділянці понад 30 років. Насіння було привезено з Узбецького НДІ рослинництва. Назва сорту не збереглась.

Висіваємо канатник в I-II декаді травня широкорядним способом, з міжряддям 60 см. Глибина загортання насіння 3-4 см. У сівозміні канатник розміщуємо після зернових і зернобобових. Для композицій використовуємо як допоміжний або формоутворюючий матеріал, плоди висушені на рослині. Розмір плодів - 2-3 см у діаметрі. Термін збирання для аранжування - II-III декада вересня.

Кенаф (Hibiscus cannabinus L.) - однорічна рослина 3 родини Мальвових (Malvaceae), високоврожайна луб'яна культура. Дикорослі види кенафу трапляються в Південній Америці. Рослина культивується в Індії, Китаї, Ірані та в деяких країнах Африки та Америки. Також ця культура поширена в Узбекистані та в Киргизстані. У незначній кількості його висівають на півдні Казахстану та на Північному Кавказі (Kenaf, 2019).

Кенаф висіваємо в пізні терміни - в I-II декаді травня. У сівозміні розміщуємо після озимих хлібів, просапних, зернових бобових. Спосіб сівби широкорядний, відстань між рядами 60 см. Глибина загортання 3-4 см.
Для композицій використовуємо плоди. Плід кенафу - щільно вкрита жорсткими волосками, п'ятигніздна коробочка завдовжки 2-2,5 см і завширшки 1-2 см. У коробочці містяться до 20 насінин. На одній рослині утворюється 20-30 коробочок. Під час дозрівання коробочки розкриваються.

Насіння було привезено з Узбецького НДІ рослинництва. Назва сорту не збереглась. Для композицій використовуємо, як матеріал-наповнювач, плоди, висушені на рослині. 3бір матеріалу для аранжування - II-III декада вересня.

Сафлор красильний (Carthamnus tinctorius L.) належить до родини Айстрові (Asteraceae). Вирощують переважно як олійну культуру, перспективну для посушливої зони півдня України. Сафлор здавна відомий в Індії, Сгипті, Китаї, Північній Африці, Середній Азії, Закавказзі. В Україні його почали вирощувати 3 другої половини XVIII ст. (Zhatov et al., 2013).

Вирощуємо сорти "Сонячний" та "Добриня" селекції Інституту олійних культур Національної академії аграрних наук України (м. Запоріжжя) (Reiestr, 2019). У ciвозміні сафлор розміщуємо після просапних культур. Сіємо наприкінці квітня, широкорядним способом із міжряддям 45 см. Глибина загортання насіння 5-6 см.

Для створення композицій використовуємо суцвіття - багатоквітковий конічний, куполоподібний кошик діаметром 2,5-3 см. На одній рослині формується до 20 кошиків діаметром до 3,5 см. Час збирання - IV декада липня після повного висихання на рослині. В аранжуванні можна застосовувати як основний матеріал або матеріал-наповнювач.

Розторопша плямиста (Silybum marianum (L.) Gaertn.) належить до родини Айстрові (Asteraceae). Інші назви цієї рослини - чортополох молочний, дарунок діви Mарії, жабник (Vorontsov \& Opara, 2010). Silybum від грецького слова, що переводиться як "пензлик". А друге слово додано на честь Богоматері. Завдяки їі цілющим властивостям іiї ще називають "дарунком Діви Марії". Батьківщина - Середземномор'я. Поширена в Західній і Центральній Свропі, південних районах Росії та України, Західному Сибіру, а також в Америці, Азії, Шотландії (Koryliak, 2013). В Україні розторопша найпоширеніша у південних областях (Херсонській, Миколаївській, Одеській) та в Криму (Khomina \& Nedilska, 2011).

Вирощуємо сорти "Бойківчанка" (селекції ІваноФранківського інституту агропромислового виробництва НААН) та "Полтавка" (селекції дослідної станції лікарських рослин Інституту агроекології і природокористування) (Reiestr, 2019). Сівбу проводимо в ранні терміни. Оптимальний термін збігається зі сівбою пізніх ярових культур. У сівозміні розміщуємо після озимих зернових або просапних культур. Спосіб сівби широкорядний. Глибина загортання насіння - 3-4 см.

Для композицій використовуємо суцвіття - кошики до 6 см у діаметрі. Зрізуємо кошики після повного висихання. Термін збирання для аранжування - перша декада вересня. У композиціях розторопшу можна використовувати як основний матеріал та матеріал-наповнювач. Внаслідок проведених досліджень встановлено, що серед малопоширених сільськогосподарських культур $\epsilon$ види, які мають декоративні властивості та можуть бути використанні в навчальному процесі під час 
вивчення дисциплін "Основи аранжування" та "Фітодизайн" (фото 1, 2).

Оволодіння навичками створення композицій $є$ органічною складовою частиною у формуванні професійної компетентності студентів спеціальності "Садовопаркове господарство". Консервовані аранжувальні рослини - це природний матеріал, який дає змогу забезпечити навчальний процес із відповідних дисциплін упродовж навчального року.

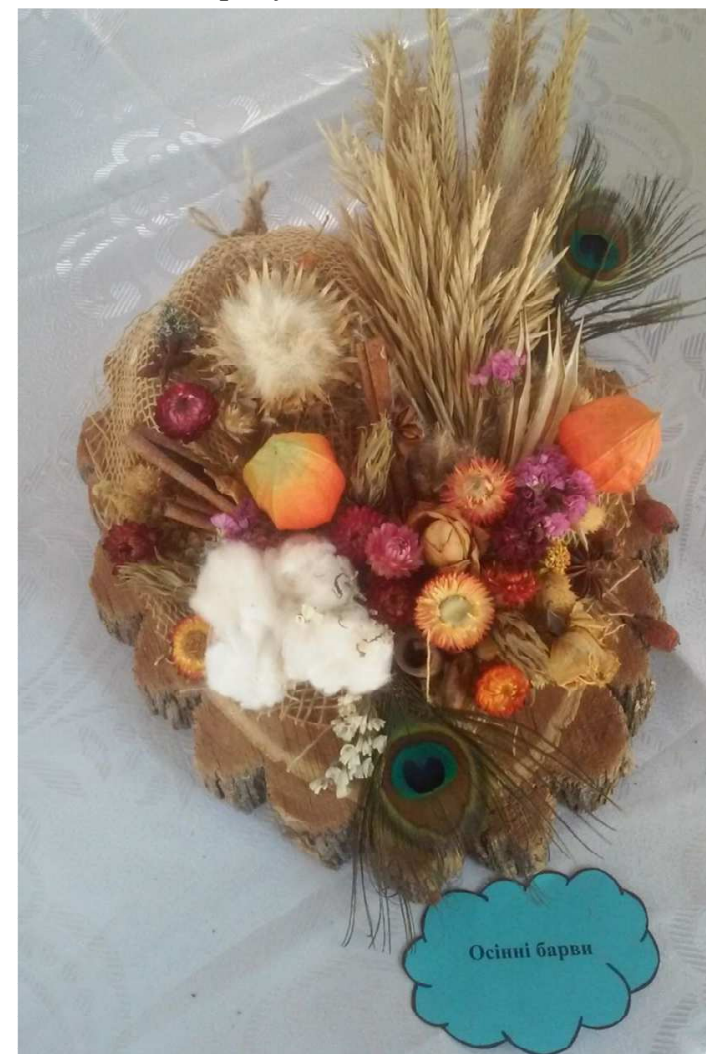

Фото 1. Панно "Осінні барви" з використанням Gossypium hirsutum, Hibiscus esculentus, Silybum marianum

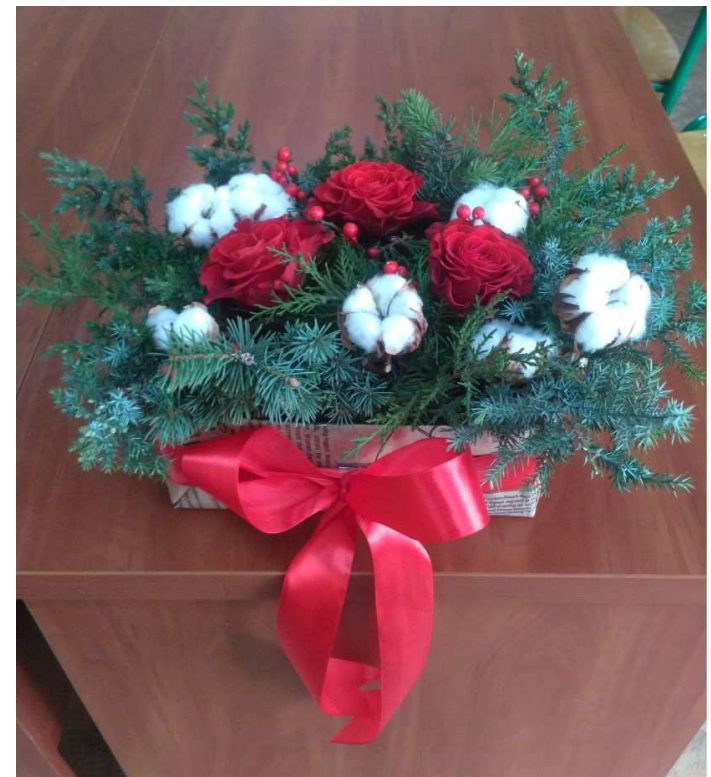

Фото 2. Зимова композиція з використанням Gossypium hirsutum як додатковий матеріал
Окрім цього, перевагами цього рослинного матеріалу $є$ оригінальність, доступність, простота вирощування та тривалість зберігання. Його можна використовувати для композицій як формоутворювальний, основний та як матеріал-наповнювач. Плоди (суцвіття) досліджуваних рослин придатні для тривалого зберігання та використання в аранжуванні.

3 об'ємно законсервованих рослин можна створювати аранжування, аналогічні композиціям із живих квітів, а також інші композиції. Безперечно, в процесі роботи з ними необхідно враховувати, окрім добору асортименту рослин, ще й закони композиції. Тільки за таких умов можна досягти якісного професійного результату.

Отже, на підставі наведених даних вважаємо, що вивчення декоративних властивостей деяких видів малопоширених сільськогосподарських культур, особливостей вирощування та оцінка композиційного використання $є$ підгрунтям для застосування їх у декоративній флористиці та розширення асортименту рослин, які можна використовувати для складання композицій протягом усього року.

\section{Перелік використаних джерел}

Diachuk, P. V., Perfilieva, M. V., \& Perfilieva, L. P. (2013). Floristy. Uman: PP Zhovtyi, 182 p. [In Ukrainian].

Kenaf. (2019). Kenaf - priadyvni kultury. (Date of treatment: 17.02.2019). Retrieved from: https://school.home-task.com/kenafpryadivni-kulturi/. [In Ukrainian].

Khaleba, V., \& Unuchko, O. (2013). Tekhnolohiia vyroshchuvannia bamii. Plantator, 8, 92-93. [In Ukrainian].

Khessaion, D. G. (2004). Vse ob aranzhirovke tcvetov. Moscow: Kladez-Buks, 128 p. [In Russian].

Khomina, V. Ya., \& Nedilska, U. I. (2011). Pokaznyky produktyvnosti roslyn roztoropshi pliamystoi (Silibum marianum L.) zalezhno vid zastosuvannia biolohichno aktyvnykh preparativ za riznykh sposobiv sivby. Agrobiology, 6, 90-95. Bila TSerkva. [In Ukrainian].

Koryliak, M. Z. (2013). Fitoterapevtychni vlastyvosti roztoropshi pliamystoi ta yii vykorystannia v hodivli tvaryn. Fishery science of Ukraine, 4, 97-107. Kyiv. [In Ukrainian].

Lebedeva, G. F. (1985). Polevye kultury. Moscow: Planeta, 16 p. [In Russian].

Mishchenko, S. V. (2012). Znakhidky Abutilon theophrasti Medik na pivnichnomu skhodi Ukrainy. Taurian Scientific Bulletin, 80(2), 399-402. Kherson. [In Ukrainian].

Pozniak, O. V., Kharytskyi, M. V., \& Malenko, A. M. (2007). Bamiia (hibisk yistivnyi). Nizhyn: TOV Publishing House "AspektPolihraf", 28 p. [In Ukrainian].

Puzyrenko, Ya. V. (2013). Decorative floristry. Kyiv: Kondor, 232 p. [In Ukrainian].

Reiestr. (2019). Derzhavnyi Reiestr sortiv roslyn, prydatnykh dlia poshyrennia v Ukraini na 2019 rik. (Valid state of: 16.01.2019). Vyd. ofits. Kyiv: Ministry of Agrarian Policy and Food of Ukraine, 451 p. [In Ukrainian].

Rozemi, Sh.-Sh. (1997). Floristika. Bukety s kompozitciiami iz zasushennykh tcvetov. Moscow: VNEShSIGMA, 87 p. [In Russian].

Tabunshhikov, N. P. (2006). Tcvety i tvorchestvo. Rukovodstvo po floristike. Kyiv: Novyi druk, 208 p. [In Russian].

Vorontsov, V. T., \& Opara, M. M. (2010). Dosvid vyroshchuvannia roztoropshi pliamystoi na nevelykykh diliankakh ta vykorystannia yii $\mathrm{z}$ metoiu ozdorovlennia. Bulletin of the Poltava State Agrarian Academy, 2, 41-45. [In Ukrainian].

Zhatov, O. H., et al. (2013). Tekhnichni kultury. Sumy: University book, 359 p. [In Ukrainian]. 
Yu. L. Bredykhina1, N. M. Turovtseva', O. E. Pyurko', L. G. Velcheva ${ }^{2}$

${ }^{I}$ Khortytsia National Academy of Education and Rehabilitation, Zaporizhia, Ukraine, Ukraine

${ }^{2}$ Bogdan Khmelnitsky Melitopol State Pedagogical University, Melitopol, Ukraine

\section{EXPERIENCE OF CULTIVATION, HARVESTING AND USE OF PLANT MATERIAL OF RARE} AGRICULTURAL CROPS IN ARRANGING

The authored works, including dry plant material, are recently becoming increasingly popular. Artistic compositions made of preserved plants do not require special care, and in combination with interesting materials look bright and spectacular and preserve the natural beauty of plants for a long time. Modern preservation technology of the arrangement material allows ensuring its high quality; therefore it is as beautiful and original as live flowers. During the study the authors applied special and general research techniques, laboratory and phytodynamics in particular. We have revealed that that fruits (inflorescences) of rare agricultural crops have high decorative character and can be used as dry (preserved) vegetative material in volumetric and semispecific varieties of compositions as a forming, main and secondary material. These are such plants as ordinary cotton, bamia, kenaf, cannate, safflower dipping and thistle spotted. It is advisable to use a natural way of bulk preservation for them, i.e. drying in the field. In addition, the benefits of this plant material are its originality, accessibility, ease of cultivation and storage duration. It can be used in the learning process to get skills for creating tracks for students. The results of visual perennial observations showed a high drought tolerance of these plants in the conditions of the Agrobiological complex of Bogdan Khmelnitsky Melitopol State Pedagogical University. The investigated plants without noticeable damage can withstand prolonged periods of drought, which are characteristic for the Southern steppe and do not require special conditions of cultivation. Thus, on the basis of the given data, we believe that the study of the decorative qualities of some types of rare crops, the characteristics of cultivation and evaluation of compositional use are the basis for their application in decorative floristics and the expansion of the plant range that can be used to make compositions throughout the year.

Keywords: collection plot; annual plants; preserved vegetative material; composition; learning process; decorative floristry. 